\title{
残胃のリンパ流に関する研究
}

\author{
福岡大学医学部第 1 外科 \\ 梅野 寿実 有馬 純孝 志村 秀彦

\section{LYMPHATIC FLOW AROUND THE REMNANT STOMACH IN CANINES AFTER PARTIAL GASTRECTOMY}

\section{Toshimi UMENO, Sumitaka ARIMA and Hidehiko SHIMURA}

The 1st Department of Surgery, School of Medicine, Fukuoka University

イヌを用いて胃幽門側部分切除を施行し，術後 6 カ月目に残胃浆膜下に色素を注入して残胃のリン パ流を実験的に㭘索した。実験群は，(1)左胃動脈下行枝切離 $(n=16)$ ，(2)左胃動脈根部切離 $(n=14)$, (3)(2)十第 3 群までのリンパ節摘出 $(n=15)$, (4)(2)+第 2 群までのリンパ節摘出 $(n=16)$ の 4 群に分け て施行した。(1)群ではリンパ流の変化はほとんど無かった。 (2)(3)(4)群ではリンパ路の遮断のため副リ ンパ路による新生リンパ路が出現していたが, No. (8)(12)(13)のリンパ節摘出の有無にて(2)(3)(4)群の残胃 リンパ流に差違がみられた。 またリンパ節摘出のみでは正常のリンパ流を回復する傾向がみられた。 残胃のリンパ流を知るには初回の手術法を確実に把握する必要がある。

韭引用語：残胃リンパ流，新生リンパ路

\section{緒 䓂}

最近，残胃の癌福の報告が増加し注目を浴びるとと もに積極的な外科的治療が施行される様になった が2)，手術上の問題となる残胃の癌におけるリンパ節 転移については未だ不明なことが多い，残胃のリンパ 流についても広瀬了や米沢ら4などの報告がみられる が十分に解明されているとは言い難い.今回，われわ れは雑種成犬を使用し，臨床において施行されている 手術に沿った胃幽門側部分切除術およびリンパ節摘出 術を行い，おのおのの手術例に叔ける生存したままの 状態での残胃のリンパ流について実験的に検討したの で報告する。

\section{対象および実験方法}

1. 実験対象および麻酔法

対象は8〜 12kg の雌雄の雑種成犬を使用した。実験 における麻酔法は気管内扱管による全身麻酔を行い， 麻酔隹はSomnopentyl (Sodium pentobarbital) 26 $\mathrm{mg} / \mathrm{kg}$ を静脈内注射した。

2. リンパ管観察法

リンパ管の観察は開腹時, 胃切除直後および 6 カ月

$<1985$ 年 9 月 11 日受理 $>$ 別刷請求先：梅野 寿実 テ814-01 福岡市城南区七隈 7-45-1 福岡大学医 学部第 1 外科
後の再開腹時に胃浆膜下へのメチレンブルー色素注入 法にて行った. 注入量は約 $1 \mathrm{ml}$ であった.リンパ管の確 認は，(1)リンパ節に流入する。（2)弁がみられる。(3)形 が不規則不整である.（4)色素の進入していく状態が明 確である。などの所見より血管系との判別は可能で あったが, 判別不可能なものは除外した。

3.イヌの正常胃におけるリンパ流の観察および手 術術式

上腹部正中切開にて開腹後, 胃癌取扱い規約 ${ }^{5}$ に準 じて胃を上部, 中部, 下部の 3 部位に分け, 小弯側捻 よび大弯側の浆膜下に色素を注入して正常胃のリンパ 流を検索した。

正常胃のリンパ流検索後, 次のよらな手術を施行し た（表 1 ).

$\mathrm{A}$ 群（左胃動脈上行枝温存, 胃幽門側部分切除術 群）：左胃動脈の上行枝は温存して下行枝は第 1 枝よ り切離し, 大弯側は短胃動静脈を温存して中山式胃腸 吻合器を用いて幽門側 $1 / 2$ 切除を行った. 断端縫合部は 浆膜筋層縫合を加えて埋没した。この術式は胃の良性 疾患に施行されている手術法に準じた。本実験には16 頭のイヌを使用し, 再建はビルロート I 法 7 頭, II 法 9 頭であった.ビルロートII法はいずれる前結腸経路 で，吻合はポリグリュール酸縫合夈 (Dexon 4-0号) 
表 1 対象および手術術式

\begin{tabular}{|c|c|c|}
\hline 界幽问侧部分切除群 & & \\
\hline 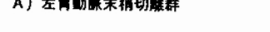 & 16 頙 $<-I I$ & 9 留 \\
\hline 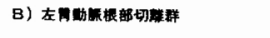 & 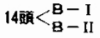 & 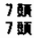 \\
\hline 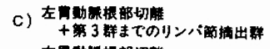 & 15 䫄 $<\begin{array}{l}\mathrm{B}-\mathrm{I} \\
\mathrm{B}-\mathrm{II}\end{array}$ & $\begin{array}{l}8 \text { 政 } \\
730\end{array}$ \\
\hline 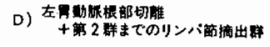 & 16 頝 $<$ B-II & $\begin{array}{l}8 \text { 䐓 } \\
80\end{array}$ \\
\hline
\end{tabular}

による全層連続吻合を行ったが，後壁は 1 層吻合，前 壁は綟糸による浆膜筇層結節吻合を付加した。

$\mathrm{B}$ 群(左胃動脈根部切離, 胃幽門側部分切除術群)： 左胃動静脈を根部で切離し，食道胃接合部より胃角上 部まで小網を胃壁より切離して $\mathrm{A}$ 群と同様幽門側 $1 / 2$ 切除術を施行した。 14頭のイヌを使用し，再建はビル ロートI 法 7 頭, II 法 7 頭であるが吻合法はA群と同 様に施行した。

C 群（左胃動脈根部切離，胃幽門側部分切除，第 3 群までのリンパ節摘出術群)：B群之同様に胃幽門側 部分切除術を行らとともに小網, 大網の切除, リンパ 節の摘出を行った。胃切除施行前に胃の各部位に注入 した色素により染色された各経路のリンパ節はすべて

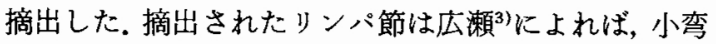
リンパ節(以下リンパ節は略す)，幽門上，幽門下，脾 門, 脾動脈幹, 脾動脈根, 左胃動脈, 総肝動脈, 幽門 後, 膵十二指腸の各リンパ節であり, 胃癌取扱い規約 ${ }^{5)}$ によれば右噴門リンパ節(1)(以下リンパ節は略す)，小 弯(3)，幽門上(5)，幽門下(6)，総肝動脈幹(8)，腹腔動脈 周囲(9), 脾門(10), 脾動脈幹(11)，肝十二指腸間膜内(12), 膵後部(13)のおのおのリンパ節に相当し, 胃下部の癌に おける等 3 群リンパ節郭清術に準じた。な和著者らは, 広瀬了のいら左胃動脈リンパ節は解剖学的にみて総肝 動脈拉よび腹腔動脈により近く存在すること,および, できるだけ胃癌取扱い規約 ${ }^{5} に$ 準じるために本文中で は総肝動脈リンパ節および腹腔動脈周囲のリンパ節と

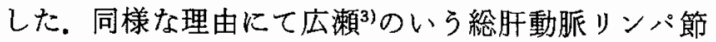
は本文中では門脈リンパ節(胃癌取扱い規約5)では肝 十二指腸間膜内リンパ節(12)に相当) とし，幽門後リン パ節・荤十二指腸リンパ節は門脈リンパ節および傘後 部リンパ節とした。実験にはリンパ節にはイヌ15頭を 使用し, 再建はビルロートI法 8 頭, II法 7 頭で, 吻 合法は A, B 群と同様に施行した。

$\mathrm{D}$ 群（左胃動脈根部切離, 胃幽門側部分切除, 第 2 群までのリンパ節摘出術群)：手術方法はC 群と同様 であるが，色素に染まったリンパ節を選択的に摘出し 一部は温存した。すなわち，門脈および满後部リンパ
節 (広瀬)のいう総肝動脈，幽門後，荤十二指腸リンパ 節）および脾門のおのおのリンパ節を温存したが，胃 癌取扱い規約 ${ }^{5}$ によれぱ脾門(10), 肝十二指腸間膜内(12), 荤後部13のおのおのリンパ節を残したことになり，胃 中部から胃下部の胃癌における第 2 群までのリンパ節 郭清術に準じた。実験にはイヌ16頭を使用し，再建は ビルロートI法 8 頭, II 法 8 頭で, 吻合は A, B, C 群 に準じた。

\section{実験成績}

1.イヌの正常胃に扮けるリンパ流

1）左胃動脈経路（以下 LGA 経路と略す）：胃体部, 胃穹隆部領域の小弯括よび前後壁に注入された色素は 左胃動静脈の末梢より左胃動静脈の本幹の中枢側に向 かって流れ, 脾動脈幹, 総肝動脈扝よび腹腔動脈周囲 のリンパ節に流入した。

2）後胃経路（以下 PG 経路亡略す）：胃窎隆部大弯 側寄りに注入された色素は，前後壁ともに大弯より左 の横隔膜直下の後腹膜を経由して脾動脈幹リンパ節に 流入した。

3）脾動脈経路（以下 SA 経路と略す）：胃体部の左 半分大弯寄りに注入された色素は，大弯より左罢大網 動静脈または短胃動静脈より脾動静脈に沿って進み, 脾動脈に沿って存在する脾門および脾動脈幹のリンパ 節へ流入した。

4）幽門経路：胃前庭部に注入された色素は 2 通り の経路が観察された。 @右胃動脈経路(以下 RGA 経路 と略す). 前庭部小弯和よび小弯寄りの前後壁より右胃 動脈に沿って流れ，さらに門脈および莁後部のリンパ 節へと流入した。 (b)右胃大網動脈経路(以下 RGEA 経 路と略す). 前庭部大弯および大弯寄りの前後壁より右 胃大網動脈の根部へと進み，根部の幽門下リンパ節に 流入した後胃十二指腸動脈に沿って門脈リンパ節へと 流入した。

2. 術直後における残胃のリンパ流

各群について術直後直ちに残胃に再度色素を注入 し, 術直後の色素の流れを確認した.

A，B 群では LGA 経路を検索するために残胃断端 縫合部の中央前壁側に色素を注入した，A群では10頭 の5ち8頭において左胃動脈の上行枝を通って LGA 経路に流入するのが観察されたが，B群ではすべて残 胃小弯扣よび断端縫合部で色素の流れは停滞した。

C群では断端縫合部前壁に注入された色素は小弯和 よび断端縫合部に和いてB群同様すべて停滞し，また， 残胃大弯に注入された色素は SA および PG 雨経路と 
もにリンパ節摘出部において停滞した。

$\mathrm{D}$ 群でも断端縫合部に注入した色素はC 群と同様で あるが, 残胃大弯に注入した色素は, SA 経路では温存 した脾門部のリンパ節に流入し同リンパ節で停滞する ものもみられたが，多くはSA 経路に沿って流れ脾動 脈幹のリンパ節摘出部にて流れが止まった。

このように術直後では色素の流れはリンパ路遮断部 ですべて止まり，それ以外の色素の流れはまったくみ られなかった。

3. 術後 6 力月目の残胃のリンパ流

全例術後 6 力月目に再開腹し, 色素を注入して残胃 のリンパの流れを検索した。

1) A群：A群では LGA 経路の 1 部が遮断されて いるので, LGA 経路領域である残胃断端縫合部抢よび 吻合部について検索した。癒着があるため, 色素注入 は断端縫合部中央で縫合部より約 $2.0 \mathrm{~cm}$ 離れた胃前 壁と，吻合部中央で約 $1.0 \mathrm{~cm}$ 離れた胃前壁にそれぞれ 注入した。

断端縫合部に注入された色素は小弯側を上行して残 存した左胃動脈の上行枝に沿って小網内に進み, さら に LGA 経路を経て腹腔動脈周囲のリンパ節へ流入す るものが大部分であり，16頭中13頭 (87\%) にみられ た、 LGA 経路へ進まなかったものは 3 頭であったが, 3 頭の内訳は色素の動きがあったくみられなかったも の 1 頭, 前壁を大弯側へ進んで SA 経路へ流入したも の 2 頭であった。断端縫合部より瘾着部を介して小網 へ進んだものが 2 頭にみられたが，リンパ節への進入 は確認できなかった。 また, SA 経路への進入は前記の 2 頭と LGA 経路へす流れた 1 頭を含めた 3 頭であっ た（図 1 ).

2）B群：LGA 経路を完全に遮断した B 群ではA 群 と同様の方法で断端縫合部および吻合部に色素を注入 した、リンパ路の完全遮断を行ったため術直後にはみ られなかった複雑なリンパの流れがみられた。

断端縫合部に注入された色素は次の 6 経路を流れる のが観察された。すなわち，(1)胃前壁を小弯側に向かっ て進み，小弯より残存小網や肝臓との間の痹着性の結 合組檥部を通って肝門部付近の後腹膜へと流れる “小 弯一後腹膜経路”は14頭中 9 頭 $(64 \%)$ にみられ，そ のうち 7 頭 $(50 \%)$ はさらに後腹膜を下行して総肝動 脈リンパ節へと流入した. (2)小弯側方向に横走して断 端縫合部を越古，庱着している小網や後腹膜へ直接進 む“断端経路”は14頭中 4 頭 (28.5\%) にみられ，そ のうち 2 頭は掞の括の門脈リンパ節拈よび残胃後壁を
図 1 左胃動脈下行枝切離胃切群（A群）

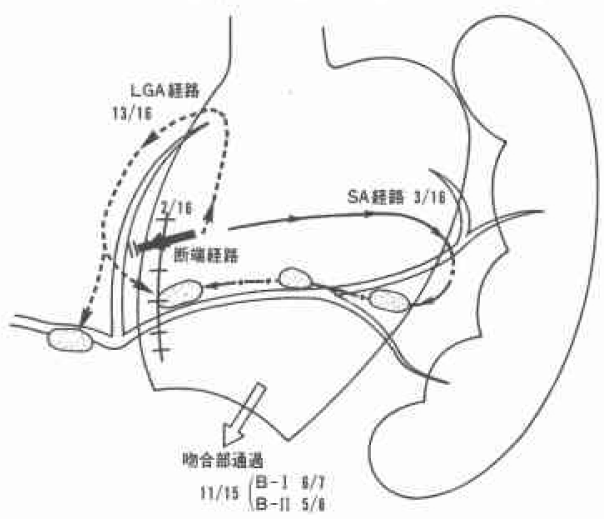

経由して脾動脈幹リンパ節へと進んだ。しかし 2 頭は リンパ節への流入はみられなかった。 (3)食道方向へ流 れる“食道経路”は14頭中 7 頭 $(50 \%)$ にみられたが, 残胃より直接に食道壁を口側に流れるすのと食道周囲 の組織内を口側に流れていくものがみられ，多くは気 管分岐部周辺のリンパ節に流入したが，途中より大動 脈方向に進むものも観察された。 (4)口側に進えだ色素 が胃食道接合部直下を大弯側に進んで残胃穹隆部大弯 側上り PG 経路に進入し，脾動脈幹リンパ節へ流入し たものは14頭中 5 頭（36\%）であった（5)断端縫合部 より大弯側に進んで $\mathrm{SA}$ 経路に進入し, 脾動脈に沿与 リンパ節へ流入したものは 14 頭中 5 頭（36\%）であっ た. (6)断端縫合部の色素が吻合部を越えて腸管へと進 んだものが 2 頭（14\%）にみられた（図 2，3）.

3） C群：第 3 群までのリンパ節摘出を行ったC群 では, 断端縫合部, 残胃大弯および吻合部胃側に色素 を注入して術後の残胃リンパ流を検索した。

断端縫合部には A，B群と同様に色素を注入した が, B群と同じく多方向への色素の流れが観察された。 (1) B群と同様に小弯より肝門部付近の後腹膜へ之進む “小弯一後腹膜経路” は15頭中10頭 $(60 \%)$ 飞観察され た。しかし，さらにいずれかのリンパ節に流入するも のはみられなかった. (2)小弯側方向に横走して断端縫 合部より癒着している後腹膜へと直接進む“断端経路” は 3 頭（20\%）にみられた。これらのうち1頭は腸間 膜根部のリンパ節へ流入したが，2 頭は断端縫合部近 傍の後腹膜にて流れが停滞した。 (3)断端縫合部より B 群と同様に“食道経路”一流れたものは7 頭 (47\%) であった. (4)B群と同様に上行した色素が窎隆部大弯 より PG 経路に進んだすのが 1 頭(6.6\%). (5)大弯側へ 
図 2 左胃動脈根部切離胃切群（B群）

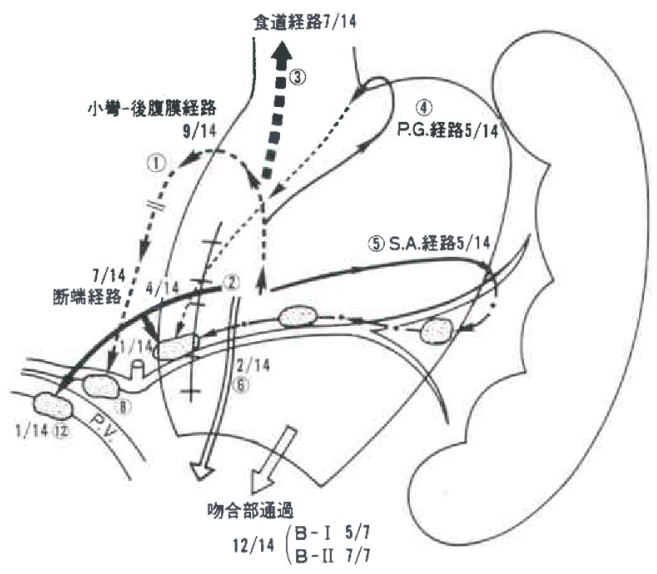

図 3 色素は食道経路や, 大弯側よりの後胃経路, 脾 動脈経路へ流れ，さらに，吻合部をこえて腸間膜の リンパ節へと流入している. 小網へも淡く色素の進 入がみられる。断端縫合部の色素はうっ滞している。

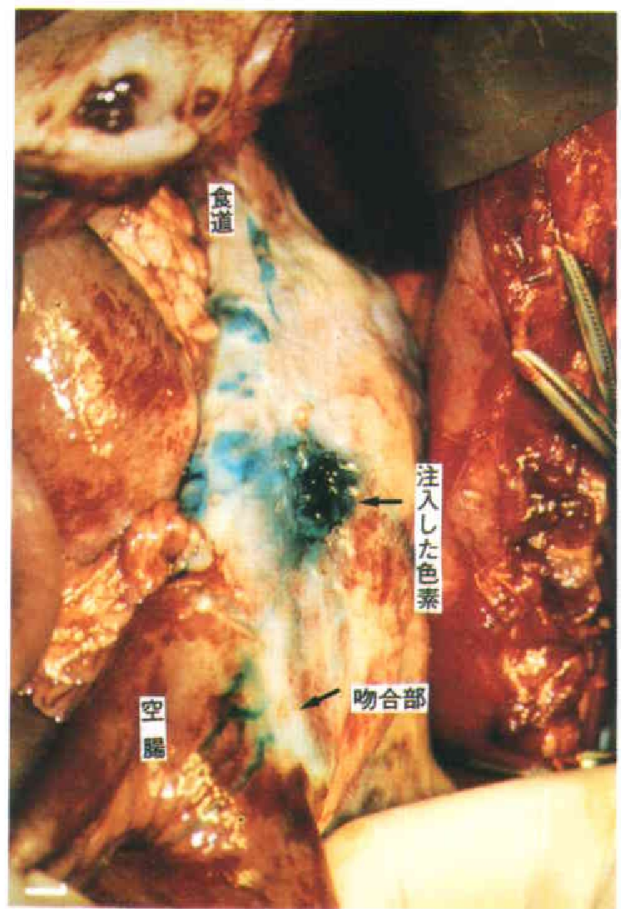

B 群における断端縫合部の色素

横走して SA 経路に進入するものが 1 頭 (6.6\%) 観察 された，色素が吻合部を越党て腸管へと進むものはみ られなかった（図4）。

$\mathrm{SA}$ 経路の検索は脾門部中央に相対する残胃大弯側
図 4 胃切十第 3 群リンパ節摘出群 (C 群)（小弯, 断 端縫合部領域の色素）

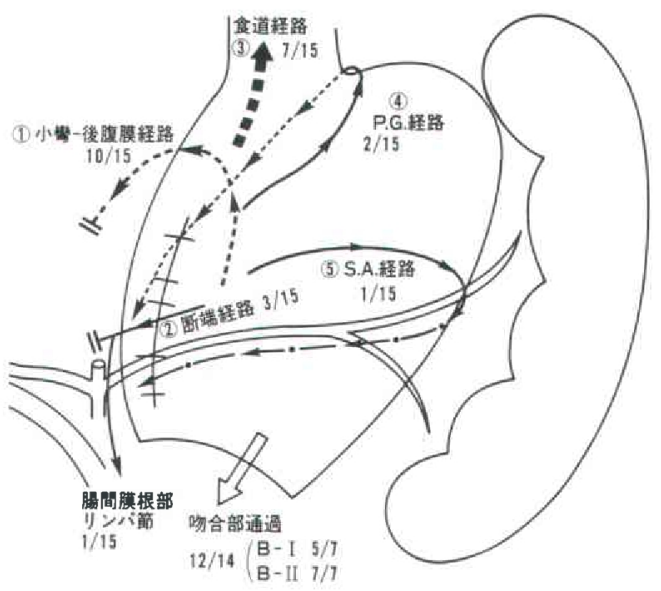

前壁に色素を注入したが，リンパ節摘出にもかかわら ず 6 力月後の検索では多くの例に SA 経路に沿う色素 の流れが観察された。15頭中 2 頭に脾動脈幹リンパ節 の取り残しがみられたため 2 頭は除外し, 対象は13頭 である、(a)弯より SA 経路に進入寸るが, 脾動脈分岐 部のリンパ節摘出瘯痕部で流れが停滞するものは13頭 中 2 頭 (15\%)，(b)脾動脈分岐部より SA 経路に沿って 進むが，脾動脈幹リンパ節摘出症痕部で流れが停滞す るもの 1 頭 $(8 \%)$, (C)ンパ節摘出症痕部を直接越点 または迂回して腹腔動脈まで流れたもの 3 頭 (23\%), (d)( よりさらに腹腔動脈下方を進んで大動脈周囲に進 入するむの 6 頭 $(46 \%)$, (e) SA 経路に進入乙脾動脈分 岐部をこえた後，膵被膜部を下方に迂回して直接大動 脈周囲に進入するもの 2 頭 $(15 \%)$ ．以上が結果である が(図 5 ), 腹腔動脈より大動脈周囲に進入した色素の 多くは上腹部の集合リンパ管である腸リンパ本幹また は腸リンパ幹網へと流れたが，大動脈周囲リンパ節に 流入するものもみられた、リンパ節摘出部を越えまた は迂回して中枢側へと流れたものは13頭中11頭(85\%) であった。

PG 経路の検索には残胃窎隆部大弯側前壁部に色素 を注入した，対象は14頭であるが色素の流れは次のご とく観察された。(i) PG 経路の輸入リンパ節である脾 動脈幹リンパ節摘出部で色素の流れが止まるもの14頭 中 5 頭(36\%), (ii) (i)よりさらに進みリンパ節摘出部を 越えて SA 経路のリンパ流に合流するもの 5 頭 $(27 \%)$, (iii) SA 経路のリンパ管には合流せずリンパ節 摘出部より大動脈方向に反転して進むもの，またはリ 
図 5 胃切十第 3 群リンパ節摘出群 (C 群)（大弯領域 の色素)

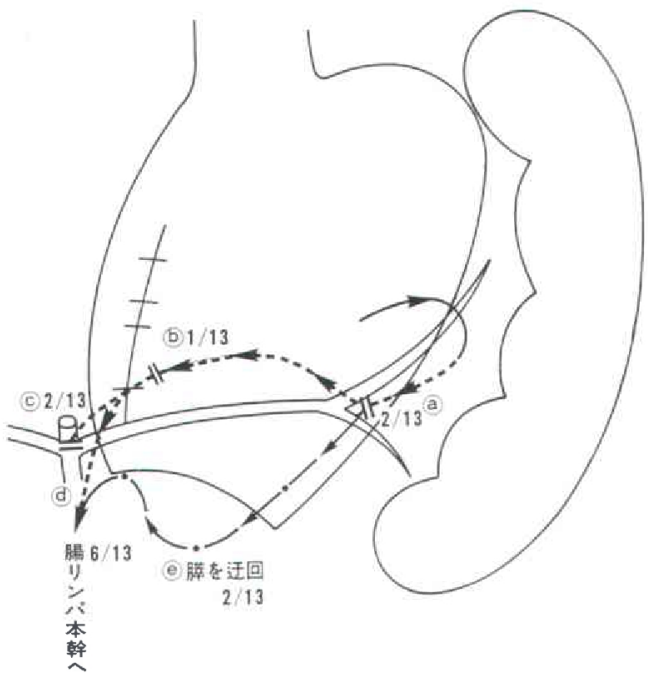

図 6 胃切十第 3 群リンパ節摘出群 ( C 群)（後胃経路 の色素)

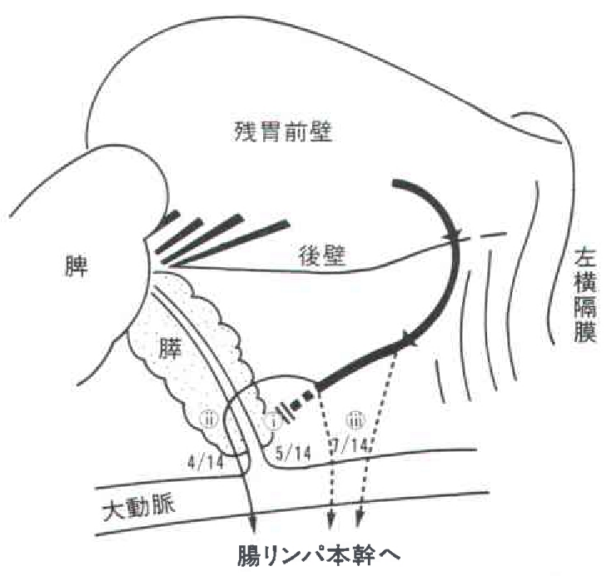

ンパ節摘出部方向へは進まずに左横隔膜直下の後腹膜 を通って大動脈方向へと進さものは 7 頭 $(50 \%)$ に観 察された(図6)。これらの(ii)(iii)の多くは腸リンパ本幹 またはリンパ幹網および大動脈周冊リンパ節へ流入し た。リンパ節摘出部を越えまたは迂回して SA 経路や 大動脈周囲へと進入したものは14頭中10頭（67\%）で あった。

4） D群：第 2 群木でのリンパ節を摘出した D群で は断端縫合部と SA 経路領域の大弯执よび吻合部に色 素を注入してリンパ流を検索した。色素注入は $\mathrm{A}, \mathrm{B}, \mathrm{C}$
図 7 胃切十第 2 群リンパ節摘出群 ( $\mathrm{D}$ 群)（小弯，断 端縫合部領域の色素)

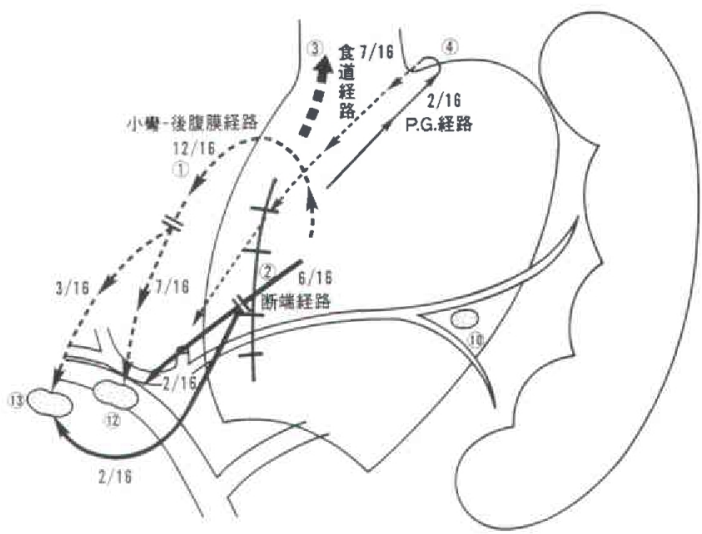

図 8 D群における断端縫合部の色素 小弯に進んだ色素は癒着性の結合組織部より肝門部 へと流れ，総胆管の背側より荤後部リンパ節へ流入 する。

食道経路へも流れている。

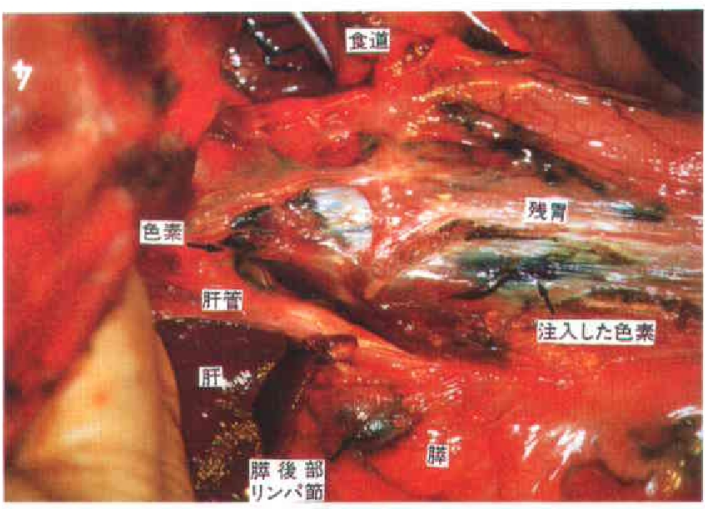

群に準じた。

断端縫合部の色素はC群とはやや異なった流れがみ られた。 (1) B, C 群之同様に “小弯一後腹膜経路”は16 頭中12頭 $(75 \%)$ に観察されたが，さらに肝門部を下 行して門脈リンパ節へ流入するものが 7 頭 $(44 \%)$, 膵 後部リンパ節へ流入するものが 3 頭 $(19 \%)$ みられた。 (2) “断端経路” は16頭中 6 頭 $(38 \%)$ に観察され，さ らに門脈リンパ節, 膵後部リンパ節に流入したものが おのおの 2 頭（13\%）にみられた。(3) “食道経路”へ は7 頭 (44\%) 流れ，(4)C群之同様に穹隆部大弯上り $\mathrm{PG}$ 経路へ進入するものも 2 頭 $(13 \%)$ 観察された. $\mathrm{SA}$ 経路招よび吻合部を越える色素の流れは観察されな かった（図 7,8）. 
因 9 胃切十第 2 群リンパ節摘出群（D群）（大弯領域 の色素)

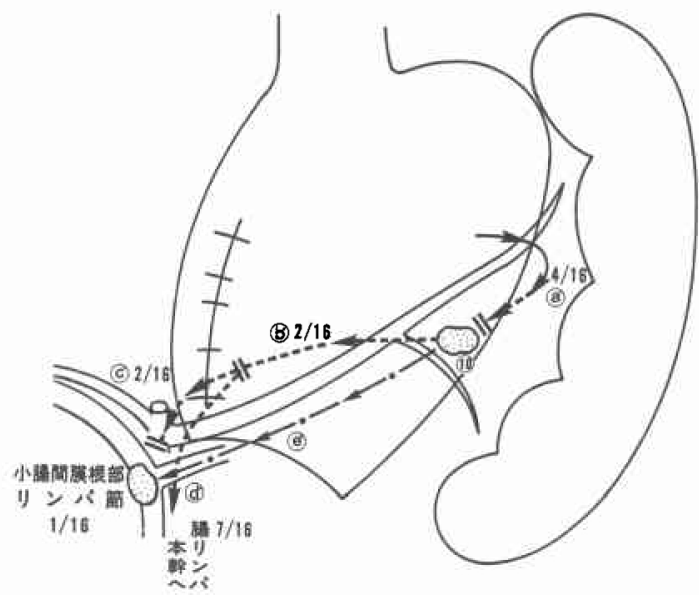

$\mathrm{C}$ 群と同じく $\mathrm{SA}$ 経路領域の大弯に色素を注入し $\mathrm{SA}$ 経路を検索したが，C群同様良好な流れが観察さ れた. 全例脾門リンパ節に流入した後は次の様な結果 であった。、同脾門リンパ節部で流れが止まるすの16頭 中 4 頭 (25\%)，(b)さらにSA 経路に沿って進むが脾動 脈幹および根部のリンパ節摘出痗痕部で流れが停滞す るもの 2 頭(13\%), (c)康痕部を越えてさらに腹腔動脈 まで達するるの 2 頭(13\%), (d) (c)よりさらに腸リンパ 本幹または腸リンパ幹網および大動脈周团リンパ節に 流入するも 7 頭 $(44 \%)$, (e)脾門リンパ節より脾静脈に 沿って流れ腸間膜根部リンパ節に流入するもの 1 頭 （6\%）であった（図 9)、リンパ節摘出部を越兄て中 权側へさらに進んだものは 16 頭中 9 頭（56\%）であっ た.

5）吻合部胃側に注入された色素の流れについては A, B, C, D 群に検討した。吻合した対側の腸管へ色素 が流れたものはA群で16頭中12頭(75\%)，B群で14頭 中12頭 (89\%)，C群で15頭中14頭 (93\%)，D群で16 頭中15頭（94\%）であり，A群に比べて B, C, D 群の 方が流れは良好であった。吻合法別に分けると，ビル ロートI 法ではA群で 7 頭中 6 頭, B 群で 7 頭中 5 頭, $\mathrm{C}$ 群で 8 頭中 7 頭, D 群で 8 頭中 7 頭, 全体では30頭 中25頭（83\%）において吻合部を越える色素の流れが 観察され，ビルロートII法ではA群で 9 頭中 6 頭， B 群で 7 頭中 7 頭， C 群で 7 頭中 7 頭，D群で 8 頭中 8 頭, 全体で31頭中28頭 (90\%) に同様の色素の流れが 観察された(表 2). ビルロートI法とII法の間には頻 度的な差は無かったが, II 法の方が色素の流れる量も
表 2 吻合部における色素の流れ

\begin{tabular}{|c|c|c|c|}
\hline 吻合法 & $B-I$ & $B-I I$ & 尌 \\
\hline$A$ & $6 / 7$ & $6 / 9$ & $12 / 16(75 \%)$ \\
\hline B & $5 / 7$ & $7 / 7$ & $12 / 14(89 \%)$ \\
\hline C & $7 / 8$ & $7 / 7$ & $14 / 15(93 \%)$ \\
\hline D & $7 / 8$ & $8 / 8$ & $15 / 16(94 \%)$ \\
\hline 計 & $5 / 30(83 \%$ & $3(90 \%)$ & \\
\hline
\end{tabular}

多くまた速度む速く流れ，腸間膜リンパ節への流入も 多くみられた。これに比べてI法では細々とした色素 の流れを示するのが多く，A，B 群では吻合部より十二 指腸へ流れた色素のリンパ節流入は荤後部リンパ節に 打の怙の 1 頭みられただけであった。しかし，I法で もC群では 8 頭中 4 頭 (50\%) に腪頭部背側に沿って 腸間膜根部りンパ節への流入がみられ，D群でも膵後 部リンパ節に 3 頭，腸間膜根部リンパ節に 2 頭の流入 があり，全体で 8 頭中 5 頭 $(67.5 \%)$ にリンパ節への 流入がみられた。

\section{考察}

胃におけるリンパの流れに関する研究は古くから多 くの報告がみられ677，その実態はかなり解明されてい るが，残胃のリンパ流に関しては不明な点が多く，わ れわれは今回実験的に残胃に扔けるリンパ流の解明を 試みた。その結果初回の手術々式の違いによって残胃 のリンパ流にかなりの変化がみられることが判明し た。

リンパ管の再生に関しては動物の四肢や耳介および 消化管を使用してリンパ路の遮断や閉塞を行った研

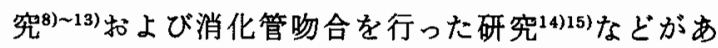
り，リンパ管の再生やリンパ路の変更が報告されてい、 る. Barry ${ }^{16)}$ によれば管径が増すほど再生の完了は 遅くなるとし, Clark ${ }^{17) や ~ O d e ́ n ~}{ }^{18119}$ は家鬼の耳介リン パ管の再生完了には30４0日を要するとし，谷川 ${ }^{14)}$ は イヌの回腸吻合後のリンパ管の再生再交通には 3 週間 を要したと報告している。他の報告11) 13)をみてる数週 間以内にリンパ管の再生は完了するとされており, 胃 切除 6 カ月後の再開腹時には残胃のリンパ管の再生も 完了しているものと思われる。しかしながら臨床に拉 ける胃切除術式は多様であり，それらの術式別に残胃 のリンパ流を検討する必要がある，したがって，本実 験では臨床に括ける各術式に沿った手術法を施行して 残胃のリンパ流を検討した。

1. イヌの残胃に和けるリンパ流 
胃良性疾患を対象とした通常の胃幽門側部分切除術 式に準拠した実験 A 群では，LGA (左胃動脈) 経路の 一部である左胃動脈の上行枝が残されているため，断 端縫合部に注入された色素の流れは LGA 経路を通り イヌ正常胃の上部小弯側のリンパの流れとほぼ同様で あった．しかし少数例ではあるが，断端縫合部から残 胃に癒着した小網や後腹膜へ直接流れる“断端経路” や SA (脾動脈) 経路への流入もみられ，術後の癒着に よるリンパ路の変更も多少は考慮すべきである.

左胃動脈を根部で切離した実験 $\mathrm{B}, \mathrm{C}, \mathrm{D}$ 群では LGA 経路が完全に遮断されたため, 断端縫合部に注入 した色素は複雑な多方向への流れがみられた，B，C，D 群いずれも術直後の断端縫合部色素注入実験では小弯 や断端縫合部で色素は停滞し、リンバ路への色素の流 れはみられなかったことから新しいリンパ路（新生リ ンパ路）が出現したことになる.

新生リンパ路にも 2 種類がみられた。.1つはリンパ 管の再生によるもので, リンパ管が遮断された残胃の 小弯や断端縫合部およびリンパ節摘出部よりリンパ管 が再生し，それらが従来の小網や後腹膜のリンパ管や リンパ節摘出部対側のリンパ管と交通してできるリン パ路で，“小弯一後腹膜経路”ゃ“断端経路”などに相 当し“再生副リンパ行路”とした。他の新生リンパ路 はリンパ管としての連絡はあるが通常はリンパ液は流 れていない経路で，別のリンパ管の遮断によりリンパ 液がそれらの経路へと流れ始めたもので“連絡副リン パ行路”とした。

“再生副リンパ行路”である “小弯一後腹膜経路” からの色素の流れは B, C, D 群に扣いて違いがみら れ,リンパ節をすべて残したB群では同経路からは総 肝動脈リンパ節に流入したが，総肝動脈リンパ節は摘 出し門脈，膵後部の各リンパ節を温存した D群では温 存した門脈，荤後部の各リンパ節に流入した。これら のリンパ節をすべて摘出した C 群では, “小弯一後腹膜 経路”から流入するリンパ節は観察されず, 癒着部や 肝門部付近の後腹膜で色素の流れは停滞した. 副リン バ行路より腸リンパ本幹やリンバ幹網へ流入すること あ考党られるが3)，肉眼的には確認しえなかった。李た “断端経路”からの色素の流れも少数ではあるが $\mathrm{B}, \mathrm{D}$ 群では門脈，荤後部の各リンパ節に，C群では腸間膜 根部リンパ節に流入していた。したがってこれらのリ ンパ節の有無は残胃のリンパ流に関して重要な意味を もっており臨床に招いても重要な問題となろら。

残胃の“連絡副リンパ路”は $\mathrm{B}, \mathrm{C}, \mathrm{D}$ 群に拈ける断
端縫合部に注入した色素の“食道経路”やSA および $\mathrm{PG}$ (後胃)経路に相当し, LGA 経路の遮断のため色素 が食道方向や脾動脈方向へ流れ出したものと考学られ る4)201.“食道経路”一流れたものが B, C, D 群ともに 半数近くにみられたが，川田 ${ }^{21)}$ や貴志ら ${ }^{22)}$ 子胃上部の リンパ路遮断により食道方向へのリンパ流がみられた と報告している。

残胃大弯側に注入した色素は，C群に打汀る SA 経 路やPG 経路拈よびD群に扔ける SA 経路ともにリン パ節摘出洀痕部を越克をたは迂回して中权側に向って 良好な流れを示しており、リンパ節摘出のみではリン パ路の変更はあまりみられず，正常胃に乱けるリンパ の流れまたはそれに近似したリンパの流れを多くは回 復するるのと思われた ${ }^{3 !}$.

リンパ管の再生は感染や炎症および廐痕化により阻 害されるといら報告がある1123224)。C群に抢ける $\mathrm{PG}$ 経路のリンパ節摘出瘢痕部で色素の流れが停滞したも のは36\%であったが，これらはいずれる症痕化が著明 なものであり，洀痕化が軽度なものの多くは症痕部を 越えていく色素の流れが観察された。このことはSA 経路でも同様であり，般痕化が著明でない場合は疫痕 部においてもリンハ管の再生再交通は出現すると考兄 られる1113)23).

消化管吻合術後に打けるリンパの流れに関してはす

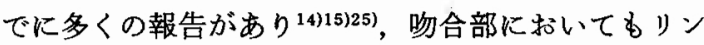
ハ管の再生再交通は認められている。 A, B, C, D 群に おいて胃腸吻合部のリンパ流を比較検討した成績で は, $\mathrm{A}$ 群に比べて B, C, D 群の方が吻合部の色素の流 れは良好であった。また，ビルロートI法にて胃十二 指腸吻合術を行った例についてリンパ節を摘出した群 (C, D 群) と非摘出群（A，B 群）との間で吻合部リン ハ流を比較したところ，前者では吻合部を越えて腸間 膜根部および膵後部のリンパ節へ流入したものが $56 \%$ にみられたが，後者では所属リンパ節への流入は汪と んどみられなかった。この事実により，胃腸吻合部の リンパの流れは胃のリンパ路の遮断範囲が拡大される ほど良好になると考兄られた。 また，ビルロートI法 に特けるC群とD群とでは，膵後部リンパ節を温存し たD群はリンパ節に流入した 5 頭中 3 頭は捇後部リン パ節に流入したが，荤後部リンパ節を摘出したC群は リンパ節に流入した 5 頭すべてが腸間膜根部リンパ節 に流入しており，荤後部リンパ節の有無にてビルロー トI 法の吻合部リンパ流の流入リンパ節にも変化がみ られている。 
ビルロートI法とII法との間では吻合部を通るリン パの流れは頻度的には全く差はみられなかったが，色 素の流れる量および速度はII法の方が良好であった。 これは胃より空腸へのリンパの流れがI法では腸間膜 方向へ直線的であるのに対し，I 法では胃からのリン パの流れが十二指腸のリンパの流れと交叉するためと 推測される.

以上のようにイヌを用いて実験的に残胃のリンパ流 の解明を試みたが，ヒトではイヌにはみられない左噴 門(2)や大弯(4529リンパ節が存在するなど条件的にや や異なる所もみられ，残胃のリンパ流すイヌとは多少 異なると思われる。しかし，ヒトに打ける残胃の癌りに おいても, 実駼結果の上うに初回手術に和ける血管処 理法やリンパ節郭清の有無, 範囲, 術後の癒着および 残胃に和ける癌の占居部位によってリンパ節転移の方 向や範囲が異なることが推測される、いずれにせよ, 臨床における残胃の癌1)特に胃癌切除後再発例では複 雑なリンハ八路の変更が考兄られ，米沢ら ${ }^{4)}$ や鈴木ら ${ }^{26)}$ も述べているように広範なリンパ節郭清が必要であろ ๖.

\section{結論}

雑種成犬を用いて胃切除後の残胃リンパ流について 実験的研究を行った。すなわち，(1) A 群：左胃動脈 下行枝切離, 胃幽門側部分切除群，（2） B 群：左胃動 脈根部切離, 胃幽門側部分切除群. (3) $\mathrm{C}$ 群 : $\mathrm{B}$ 群 + 第 3 群までのリンパ節摘出群.（4） D群：B群十第 2 群までのリンパ節摘出群の 4 群について術直後および 術後 6 力月目に打ける残胃リンパ流を比較検討し，次 のような成績を得た。

1）A群ではリンパ路が残存しているため術後の残 胃リンパ流の変化はあまりみられなかった。

2） B，C，D 群の断端縫合部領域のリンパ流は複雑な 流れがみられた。(1)小弯および断端縫合部より瘺着部 を通って後腹膜へ進むもの（小弯一後腹膜経路，断端 経路). (2)食道方向へ進むもの (食道経路). (3)大弯側 に進み大弯より脾動脈経路および後胃経路に流入する もの. (1)の “小弯一後腹膜経路”からはB群では $50 \%$

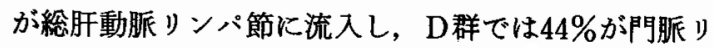
ンパ節に，19\%が荤後部リンパ節に流入したが，C群 ではリンパ節への流入はみられなかった。

3） C, D 群における大弯側のリンパ流は, 多くは正 常胃の脾動脈経路および後胃経路に沿った，または近 似したリンパ流を回復して括り，腸リンパ本幹をたは リンパ幹網掞よび大動脈周囲リンパ節への流入がみら
れた。

4）胃腸吻合部でもリンパ路の再生再交通がみられ, 特にピルロート II 法では I 法に比べてリンパの流れは 良好であった。また吻合部のリンパ流は胃周辺のリン バ路の遮断が広範用になる程流れが良好になる傾向が みられた。

5）残胃のリンパ流を把握するには初回の手術法を 確実に知る必要が㧍り, 切除された血管の種類, リン 八節郭清の有無, 術後の瘾着などが残胃のリンパ流に 大きく関与していると思われた。

本論文の要旨は第20回日本消化器外科学会 $(1982.7) \mathrm{K}$ て発表した.

1) 藤田吉四郎, 伊藤一二, 三輪 例の外科的検討. 外科 $31: 919-926,1969$

2) 城所仂: 残胃の癌切除例の遠隔成續一胃癌研究 会98施設613例の検討一. 日癌治療会誌 7:55 $-60,1982$

3）広瀬周平：胃リンパ路郭清術後の修復に関する実 験的研究. 岡山医会誌 $9: 1267-1316,1965$

4）米山 豊, 沢 敏治, 片山寛治湴か：残胃のリンパ 流ならびに残周の癌のリンバ節転移の検討. 日消 外会誌 $17: 1814-1819,1984$

5）胃癌研究会編：胃癌取扱い規約. 東京, 金原出版, 第10版, 1979

6）本田八兵衛：日本人胎児及び哺乳動物に於ける胃 リンパ管系の解剖学的研究. 熊本医会誌 5 : $720-740,1968$

7）井上興制一：冒・十二指腸・膵葴並ビ二横隔膜 淋 巴管采統. 解剖誌 9:35-117, 1936

8）大森浅吉：リンバ路閉塞に関する解剖学的検索. 鹿児島大矤誌 $21: 1-19,1969$

9）副島武雄：犬の後肢のリンパ路閉塞部のリンパ路 の変化に関する解剖学的研究 I. II. III. 鹿児島大 医誌 $20 ： 732-767,1968$

10) Chippa SA, Galli G, Lucian L: Cinsideration on the restoration of the lymphatic circulatjion after pelvis lymphadenectomy. Surg Gyencol Obstet $120: 323-334,1962$

11) Gray JH: Studies of the rebeneration of the lylmphatic vessels. J Anat $74: 309-335$, 1939-1940, 0000

12) Kocandle N, Houttuin E, Prohaska JV : Regeneration of the lymphatic after autotransplantation and homotransplantation of the entire small intestine. Surg Gyencol Obstet $122: 587-592,1966$

13) Reichert FL: The regeneration of the lymphatics. Arch Surg 13:871-879, 1926 
14）谷川允彦：外科領域におけるリンパ管系の諸問題 に関する実験的研究. 第 1 編, 消化管壁内リンパ管 造影並びに消化管吻合時のリンパ管再生. Arch Jpn Chir $47: 563-574,1978$

15）福田聂一：腸管の吻合ないし态着によるリンパ路 の改変に関する解剖学的研究. 鹿児島大医誌 $23: 1483-1515,1972$

16) Barry WF, Kern F Jr: Intestinal and liver lymph and lymphatics. Gastroenterology 55 : 408-422, 1968

17) Clark ER, Clark EL: Observations on the new growth of lymphatic vessels as seen in transparent chamners introduced into the rabbits ear. Am J Anat $51: 49-87,1932$

18) Odên $B$ : A micro-lymphangiographic study of experimental wounds healing by second intesion. Acta Chir Scand 120:100-114, 1963

19) Odén B: Experimental micro-lymphagiography. Acta Chir Scand 271(Suppl) : 1-19, 1961

20）斉藤 拓：外科的立場よりみた噴門リンパ節並び
に食道胃移行部周辺のリンパ系に関する基礎的研 究. 福岡医誌 $54: 378-409,1963$

21）川田彰得：噴門癌の食道進展に関する臨床的なら びに実験的研究. 第 2 篇, 食道胃接合部ならびにそ の付近に打ける粘膜内リンパ路に関する実験的研 実. 日外会誌 $7: 543-550,1974$

22）貴志周一郎：人食道. 胃噴門部の区割性淋巴節な らびに覀性腫場転移形成についての $2 \sim 3$ の考 察. 日外宝 $12: 862-877,1935$

23) Elosser L: Obstruction on the lymph channels by scar. J Am Med Ass $81: 1867-1870,1923$

24) Yotty JM, Couticce FC: Lymphatics Lymph and the Lymphomyeloid complex. London and New York, Academic press, p356-1020

25）益崎滋雄：イヌの胃リンパ路についての実験解剖 学的研究. 医研究 $47: 15-22,1976$

26）鈴木 博, 遠藤光夫, 小林战一郎ほか：残胃の癌の 手術治療之予後の検討. 胃と腸 $17: 1313$-1324, 1982 